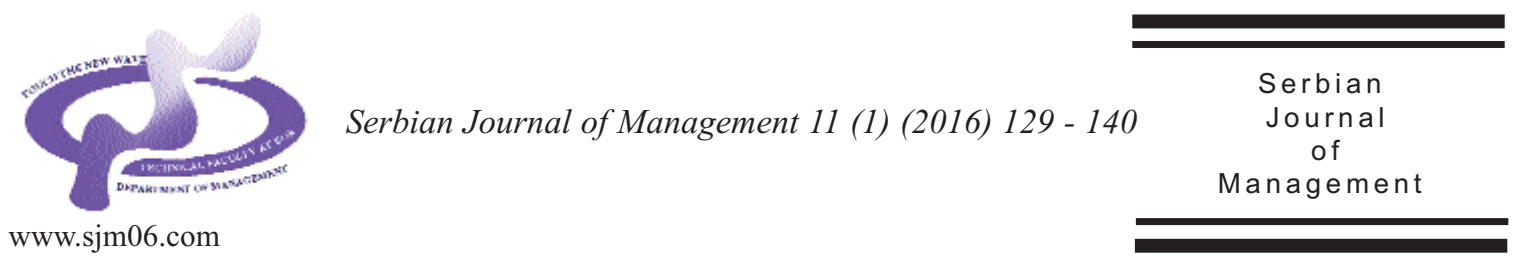

\title{
CONTINUING EDUCATION FOR MANAGERS AS THE BASIS OF INNOVATION ECONOMY (EXPERIENCE OF THE RUSSIAN PRESIDENTIAL ACADEMY OF NATIONAL ECONOMY AND PUBLIC ADMINISTRATION)
}

\author{
Elena Kosareva ${ }^{a}$ and Natalia Safronova ${ }^{b} *$ \\ a-Institute of sectoral management at Ranepa; b-Faculty of marketing, advertising and \\ services at Ranepa, 82 Vernadskogo prosp. 119571 Moscow, Russia
}

(Received 18 September 2015; accepted 19 October 2015)

\begin{abstract}
The experience of establishing a system of continuing education at the Russian Presidential Academy of National Economy and Public Administration (RANEPA) to support the institutional reform of the Russian economy was investigated. A review of the scientific research activities carried out by the Academy was provided. The role of the Academy in the formation of the educational space was demonstrated. The practice of creation of education and training cluster within a structural division of the Academy - the Institute of Sectorial Management - was evaluated as an example.
\end{abstract}

Keywords: Training of human resources, Russian Federation, Gaidar Forum, education and training cluster, institutional reform

\section{INTRODUCTION}

The Russian Presidential Academy of National Economy and Public Administration (The Presidential Academy, RANEPA), founded in 2010 as a result of merging with the Academy of National Economy under the Government of the
Russian Federation (ANE, year of establishment - 1977), the Russian Academy of Civil Service under the Russian Federation President (RACS, year of establishment - 1991), and 12 other federal state educational institutions, is a nonprofit organization established to meet educational, scientific, social, and cultural needs of

\footnotetext{
* Corresponding author:safronova@ranepa.ru

DOI:10.5937/sjm11-9090
} 
citizens and society. The Academy offers secondary vocational, higher education, and supplementary education programs, conducts fundamental and applied scientific research across a broad spectrum of disciplines, and carries out the functions of a scientific and methodological center of the Russian Federation education system in the main areas of its activity.

The Mission of the Academy is to produce flexible, globally competitive managers capable of addressing the challenges of social and economic development with professionalism and innovation in both public and private sectors (http://www.ranepa.ru/)

Accordingly the mission driven goals of the Academy are: a) to train globally competitive and adaptive managers for the innovation economy and state, public, and private sectors to address the problem of innovative development of society; b) to carry out fundamental and applied research and development activities in the socioeconomic and humanitarian areas; and c) provide scientific and expert-analytical support to state authorities of the Russian Federation.

The key competence field of RANEPA is management development in the broad context of global and national political, socio-economic, historic, legal, as well as cultural environments. Built on this broad humanitarian platform RANEPA focuses on three fundamental tasks: training of public officials, business education, and policy research (http://www.ranepa.ru/).

The functions and powers of the founder on behalf of the Russian Federation in relation to the Academy are vested in the Office of Presidential Affairs of the Russian Federation. Chancellor of the Academy, Vladimir Alexandrovich Mau (Figure 1),
Doctor of Economic Sciences, is an expert in the field of institutional economics, economic theory, history of economic thought and national economy. The special status of the Academy - the only educational institution in Russia under the President of the Russian Federation - defines the special status of the Chancellor, whose candidacy must be approved personally by the President of the Russian Federation.

In his scientific articles, the Chancellor of the Academy discusses potential options and variants of development of the Russian social policy - the problems that exist in the education, healthcare, and culture sectors, which were not included in the Strategy2020, but without which it is impossible to ensure the development of human capital. Special attention in the articles of Professor V.A. Mau is drawn to the formation of the middle class in Russia, the demands of the class regarding the quality of the education and health services as well as organization of the pension system. The problem of poverty, which acts as a barrier to social and economic development of Russia, occupies a special place in the articles of the Chancellor of the Academy (Mau \& Klyachko, 2013).

\section{ORGANIZATIONAL STRUCTURE OF THE RANEPA}

The Academy's management system is based on the principles of collective decision-making and balancing the interests of the state, society, and individuals, and includes the following:

- Conference of the academic staff, representatives of other categories of employees, and students;

- Academic Council of the Academy;

- Chancellor; 


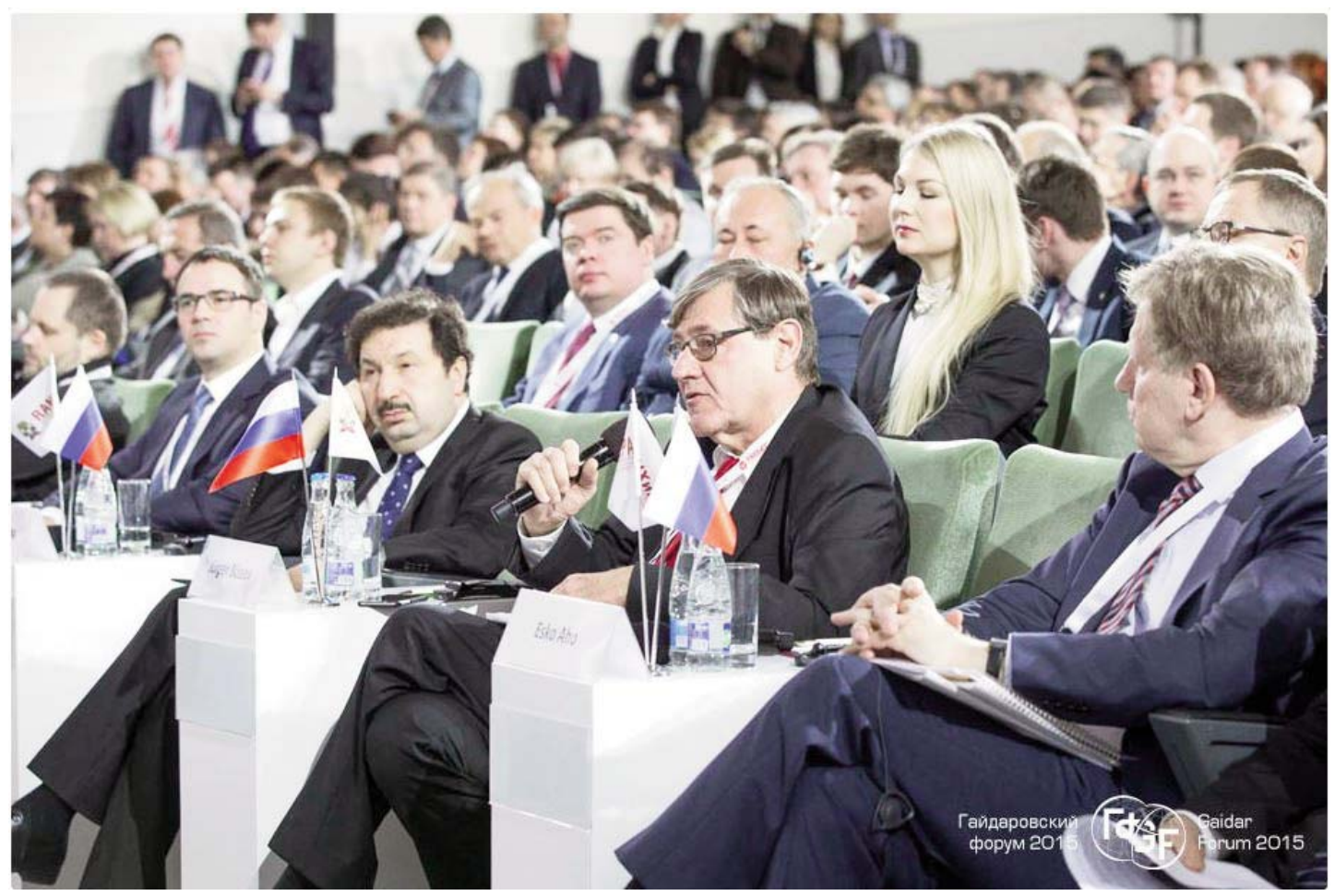

Figure 1. Rector of the Academy Vladimir Mau and representatives of the Gaidar Forum

- Board of Trustees of the Academy;

- Student Council.

The priorities of the Academy include the following:

- Establishment of a unified system of training of human resources;

- Leadership in the training methodology and geographical coverage with respect to training of state and municipal officers;

- Internationally recognized business education programs;

- Development of active teaching methods;

- Ensuring interdisciplinary and individual character of training programs;

- Analytical support of public authorities.

The educational standards of the Academy correspond to all relevant applicable requirements and ensure the formation of the necessary systemic and professional competences, individualization of the learning process, gaining of practical experience in relevant professional fields, knowledge of the English language at the internationally acceptable level, and establishment of common cultural foundation for the self-development of students.

The Academy is currently the largest educational institution in Russia whose structure comprises 5 institutes, 8 faculties, and 63 branches.

\section{EDUCATIONAL CAPACITIES OF RANEPA ACADEMY}

The Russian Presidential Academy is the largest university in Russia and Europe as a whole. With over one million gross square meters of space, RANEPA's main campus and regional branches boast facilities 


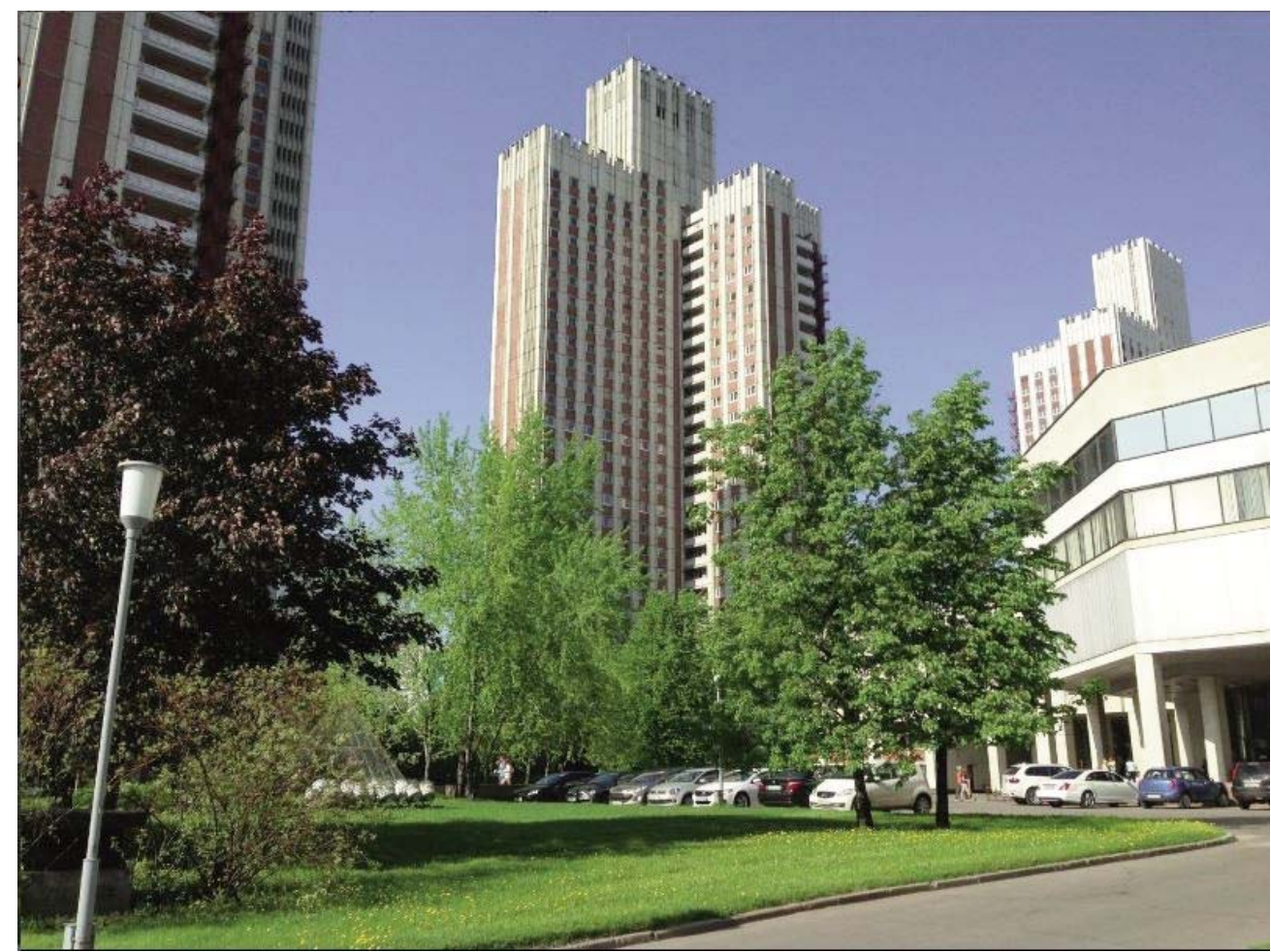

Figure 2. The building of the RANEPA campus in Moscow

abundantly equipped with modern auditoriums, libraries, sports facilities, stadiums, cafeterias, restaurants, dormitories, business centers, and guesthouses. The central building of the RANEPA academy in Moscow is presented in Figure 2.

The total number of students enrolled in higher education programs (undergraduate, specialty programs, master's degree programs) offered by the Academy and its branches equals 100,401 individuals, including 40,173 full-time students. Figure 3 shows the dynamics of the number of students studying at the Academy with allowance for the study mode (the data provided by the Educational Policy Office of the Academy).

The Academy currently offers educational programs in 59 areas of training and higher education specialties (bachelor's, specialties, master's degree programs) and over 400 additional professional education programs.

This unique combination of educational programs enables the shifting from training to re-training of human resources in order to adapt to the rapidly changing conditions of the economy and ensure high adaptability of the programs to the tasks that the Russian managers face in the modern dynamic world. The high standard of training is achieved through employment of highly-qualified research and teaching staff. The Academy currently employs 1002 academicians; 75\% of the teaching staff on average have earned advanced academic degrees.

Figure 4 shows the change in the number of students at different stages of development of the Academy. It should be noted that in the period 2007-2011, data are presented separately for the Academy of 


\section{RANEPA}

\section{Dynamics of the number of students, Moscow}

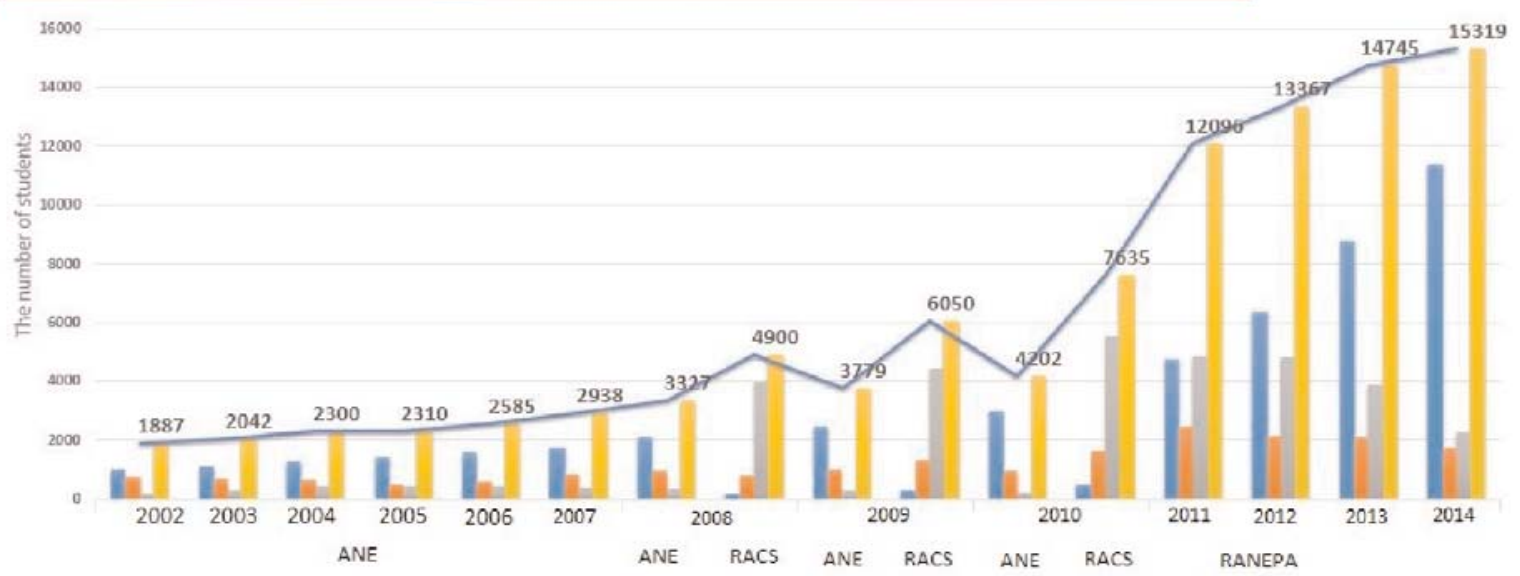

Figure 3. Dynamics of the number of students studying at the RANEPA Academy (http://www.ranepa.ru/eng/): ANE - Academy of National Economy; RAGS - Russian Academy of Civil Service; RANEPA - Russian Presidential Academy of National Economy and Public Administration

National Economy and RAGS. After the unification of educational institutions in 2012, there was a significant increase in the number of students.

Significant changes have occurred in the structure of the set for various academic programs demonstrated in Figure 4 (the data provided by the Educational Policy Office).

Comparing the results of the set after two years, after the merger of the two schools and the Academy founded we see, that the number of bachelors doubled with a slight reduction in the number of masters. The ratio between the number of budget and commercial places has changed slightly, with an overall increase in the number of students accepted to full-time training.

The high quality of education offered at the Academy is attributed not only and not so much to the highly qualified teaching staff, but to the high level of academic preparedness of the Academy entrants. The dynamics of changes in the average passing grades (Unified State Examination) for various undergraduate programs is positive.

The Academy also treasures the fact that many important individuals in Russia are RANEPA graduates. For example, $60 \%$ of all Russian federal government officials are from the Academy. Also, 40\% of Russian MBA graduates received their degrees from RANEPA.

The Academy has established extensive international connections with the leading foreign universities, including Stanford University (the USA), Harvard University (the USA), Duke University (the USA), Kingston University (the UK), as well as universities of Germany and France. The Academy not only sends Russian students abroad and implements joint programs with leading universities, but also trains foreign 


\section{RANEPA}

\section{RANEPA structure of the number full-time students}

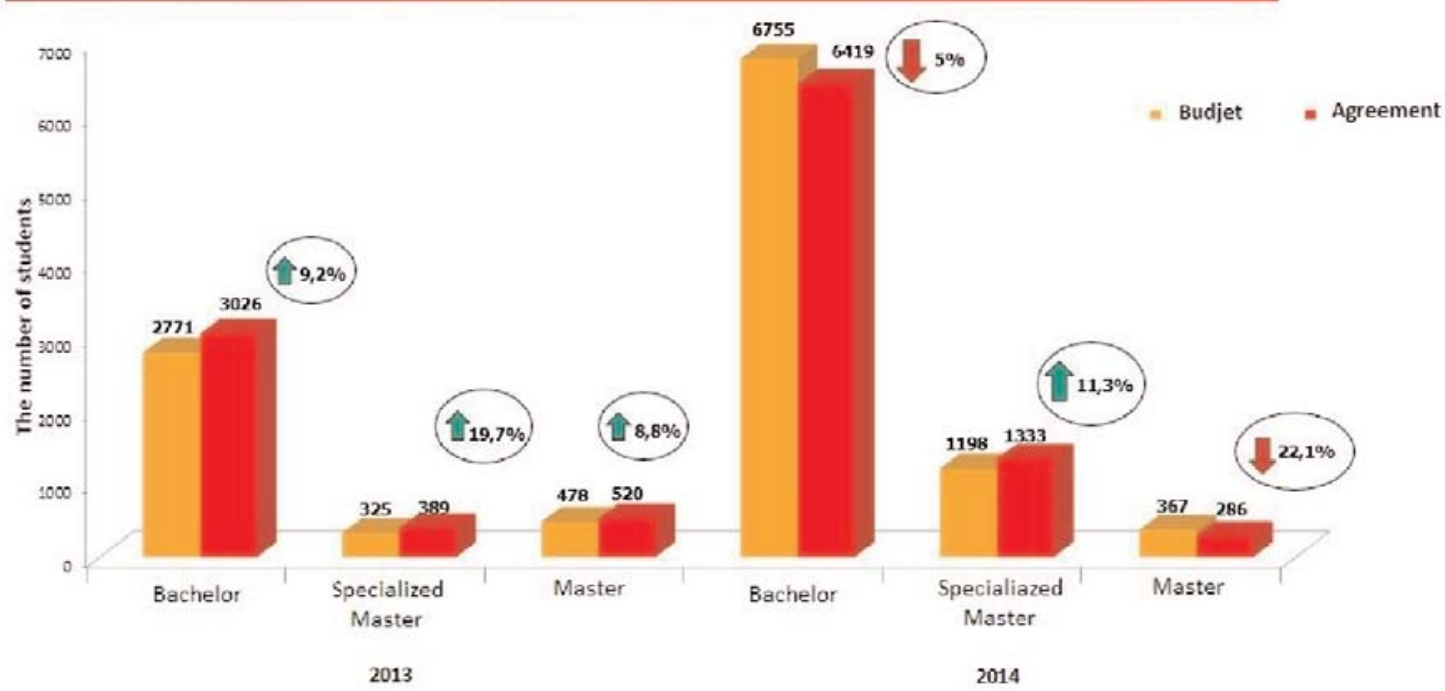

Figure 4. The structure of the set for various academic programs at 2013 and 2014 years.

students. In the 2013/2014 academic year, the total number of foreign students enrolled in higher education programs exceeded 580 individuals. Students from Germany, France, Israel, the Republic of the Congo, Serbia, and the CIS study at various branches of the Academy. The number of branches training foreign students is also increasing. Thus, the Altai Branch, the Dzerzhinsk Branch, and the North-Caucasus Institute (a branch of the Academy) accepted foreign students for the first time, while a total of 174 students from 11 countries are currently enrolled at the North-Western Institute of Management (a branch of the Academy).

The Academy successfully implements supplementary professional education programs designed to train representatives of the business community, state and municipal officers, as well as managers of various levels. The Academy traditionally maintains connections with the leading commercial organizations developing and implementing supplementary professional education programs upon request.

As part of the development strategy of the Academy, the expert group of the Academy together with the experts of the World Bank developed Regulations for evaluation of performance of various structural units of the Academy engaged in offering educational programs that must conform to the international educational standards, e.g. Doctor of Business Administration, Executive Master of Business Administration, Master of Business Administration, and Specialized Master.

Informational support of the educational process is another important condition of training of modern managers for the innovation economy. The Funds of the Scientific Library of the Academy 


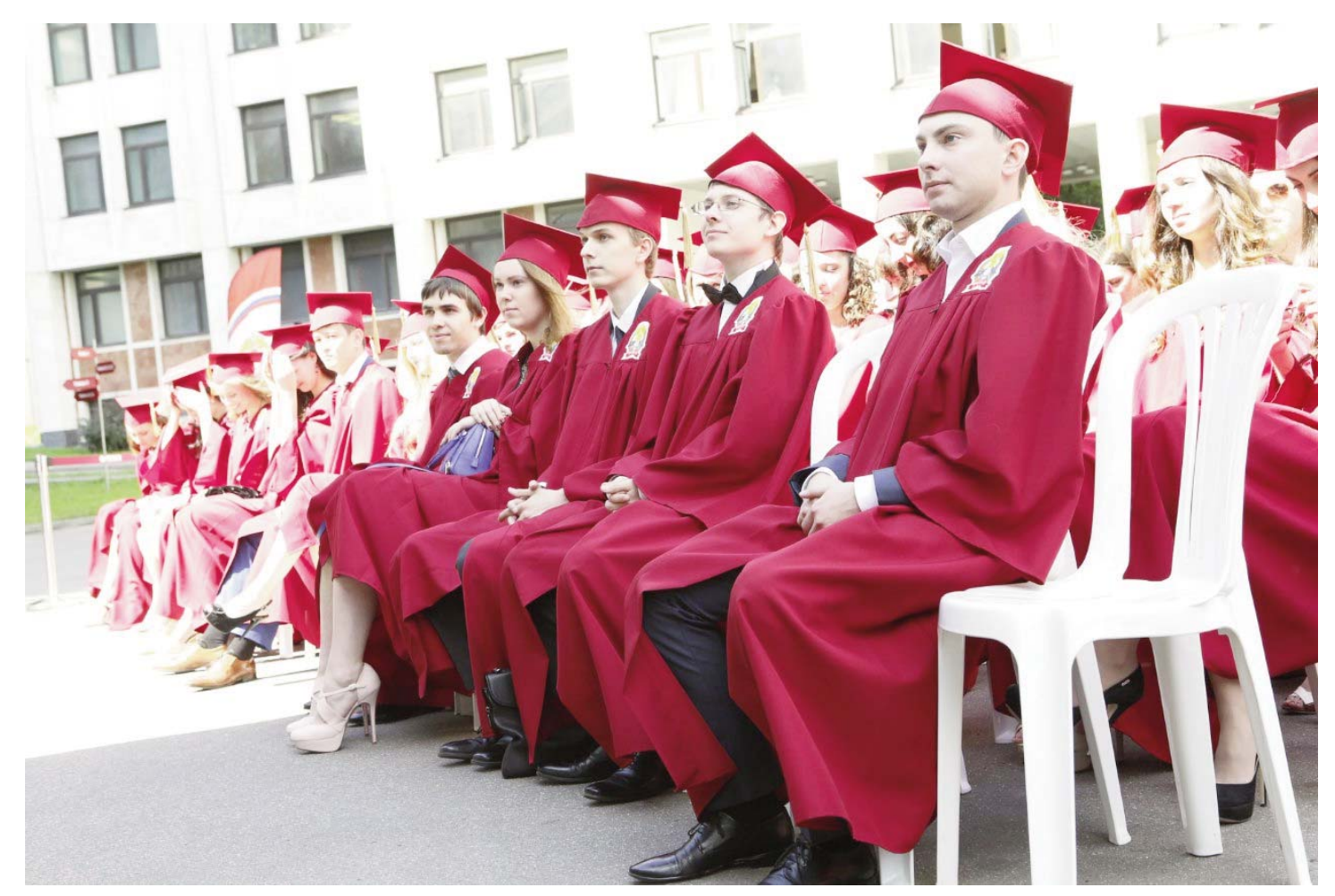

Figure 5. Graduation day of the Ranepa students-class 2015

containing 1,104,658 items, including those in foreign languages, of which 282,780 pieces of learning materials, including 83,237 compulsory publications, 112,338 works of fiction, and 710,450 pieces of scientific research have become the center of this process. A total of 911 copies of publications in electronic form on CD-media containing audio-visual materials are available at the Library. The Electronic Library System "The University Library" contains 4,220 electronic textbooks. A total of 1993 terminals currently provide access to the Electronic Library System, modern professional databases, reference information, search engines, and the Internet. All students, listeners, and teaching staff of the Academy are provided with free access to the following world science and information systems:

Annual Reviews, Bloomberg, Cambridge
University Press, EBSCO Publishing, Emerging Markets Information Service (EMIS), IMF eLibrary, JSTOR, New Palgrave Dictionary of Economics, OECD iLibrary, Oxford University Press, Oxford Handbooks Online, SAGE Publications, Science Direct, SCOPUS, Springer, Taylor and Francis, Web of Science, Wiley Online Library, World Bank Elibrary.

Each year, graduated students of the academy, are issued the diplomas on the honorary manifestation presented in Figure 5.

\section{THE RESEARCH WORK AT THE RANEPA ACADEMY}

The areas of interest of the researchers at the Academy include the following: economic history, general processes of 
economic transformation, economic growth, macroeconomic forecasts, budgetary and monetary and credit policy, tax reform, budgetary federalism, problems of social development, income and consumption of population, social policy and pension reform, economics of education, financial economics, theory and practice of corporate finance, privatization, protection of property rights, institutional and investment aspects of the post-privatization development of enterprises, strategic financial management, corporate, project, and venture funding, evolution of property relations and corporate governance, land markets and agrarian reform, housing and communal complexes and models of effective management of housing and communal services, deregulation, regional economic development, professional standards of qualifications of procurement specialists, problems of development of major economic sectors and industries, industrial markets, structural and investment policy, innovation processes in the scientific-technical and industrial organizations, external economic relations, development of human and intellectual potentials in the world economy and in Russia, management theory and practice, strategic management and marketing, strategic logistics, analysis and forecasting of political situation (political economy), analysis of the Russian and international experience of combating corruption, sociological and legal disciplines. The global experience in the field of theory and practice of economic reform is also analyzed and summarized.

The customers that order the research services from the Academy traditionally include the Administration of the President of the Russian Federation, the Government Office, the Council of the Federation of the
Federal Assembly of the Russian Federation, the Accounts Chamber of the Russian Federation, the Central Bank of the Russian Federation, the Ministry of Economic Development of the Russian Federation, the Ministry of Finance of the Russian Federation, leading consulting agencies, large corporations, and industrial enterprises.

The Academy integrates advanced research and educational programs that address the problems of innovative development within the framework of unified educational space, which represents a set of interrelated systems of training, methodological, and informational support, education quality assurance, management, planning and monitoring of the education process as well as mobility of students, graduate students, scientists, and academics.

Information and learning environment is currently being created and developed which will assist in modern implementation of the functions of teaching and management of the education process and its quality. The publication activity of the employees, students, and graduate students of the Academy in the reporting year can be evaluated using various lists and databases. The data that are considered most reliable are derived from the RISC, Scopus, and Web of Science data.

The total number of citations for all publications of the Academy indexed in the Russian and international informationanalytical systems of scientific citation for the past 5 years $-11,602$.

The results of scientific research and analytical and advisory work conducted by the Academy are traditionally discussed at the Gaidar Forum - the largest annual scientific event of international importance held in Russia in the field of economics. The Forum is traditionally opened by the Prime 
Minister of the Russian Federation.

In 2015, the Forum was held in January and was titled "Russia and the World: a New Vector". The discussions of the Forum are traditionally devoted to the position and the strategic role of Russia in the world.

The Forum represents a unique intellectual platform uniting theorists and practitioners, world's leading scientists and politicians, representatives of higher financial circles and the global business elite. Every year, the Academy attracts stars of the global economic thought, Nobel Prize winners in economics, the best teachers of the global leaders among universities (Harvard, Stanford, MIT, etc.), and representatives of the Russian political establishment, as well as higher financial and business circles. The Forum accepts all those who contribute to global order with their achievements in the economic science and exert influence on the socio-economic development of regions and individual countries. In the Russian media, the Forum has earned the reputation of the "Russian Davos Forum" included in the list of the world's leading economic conferences with respect to participant composition and the status of the experts. For guests from abroad, the Forum represents an important source of information regarding major trends in the socio-economic and political development of Russia and the state of its business environment and acts as an investment climate barometer. For local experts, participation in the Forum enables them to determine the prospects for further economic growth and integration of Russia into the world economy.

The Forum acts as a continuously operating platform for holding various events of different level of importance and scale: plenary sessions, expert roundtables, and panel discussions. The Forum moderators include high-ranking policy makers and influential experts: Russian Government officials, representatives of regional authorities, leading Russian and foreign economists and scientists. One important feature of the Forum is the active involvement of students and young scientists in its operation, who act as speakers and discussion participants along with recognized authority figures in the field of economics.

The discussions held at the Forum have traditionally been focused on the most pressing issues of modern times. Particular importance is attached to matters related to the comprehension of the position and the strategic role of Russia in the world.

In 2015, the Forum was attended by approximately 5,700 people, including hundreds of experts from dozens of countries and over 900 journalists. The participants of the Forum in 2015 included such outstanding experts as Jean-Claude Trichet, the President of the European Central Bank (2003-2011), the Chairman of the "Group of Thirty"; Christopher A. Pissarides, Regius Professor at the London School of Economics and Political Sciences, a Nobel Prize winner in economics; Immanuel Wallerstein, Professor at Yale University, one of the leading sociologists in the world; Michel Roger, the Minister of State (Prime Minister) of the Principality of Monaco; Jacob Frenkel, the Chairman of JP Morgan Chase International; Emmanuel Faber, the CEO of Danone, and many others.

\section{FINAL REMARKS}

As has already been noted, multidisciplinary approach, which is 
implemented at the Academy, is one of the main features of training of modern managers. Each of the 65 regional branches consists of institutes and departments that provide training in various areas (e.g. state and municipal management, sports management, healthcare organization, etc.) and fields (e.g. economics, law, sociology, management, marketing, economic security, etc).

The operation of the structural divisions of the Academy is considered in this text using the Institute of Sectorial Management as an example. The Institute consists of 6 faculties, 3 scientific-practical centers, and 9 departments; it offers undergraduate programs in 5 fields of training, 11 master's programs, and over 40 further education programs for various sectors of the national economy.

The Institute's missions are: a) to provide knowledge to the students and listeners of the educational programs and contribute to the formation of professional competencies for the purpose of self-realization and application of skills by the students in various areas of activity; $b$ ) to ensure training of unique specialists and leaders for various industries of the Russian economy capable of responding to the challenges of the modern market (http://www.ism.ranepa.ru/ ).

A total of 1,500 students are enrolled in higher education programs at the Institute of Sectorial Management. New educational programs are implemented every year to meet the needs of the Russian economy. Thus, a new specialization "Service in the Fashion and Beauty Industry" became available in 2015 within the framework of the "Service" undergraduate program; the Faculty of Engineering Management is currently enrolling students into the master's degree programs "Contract Manager and
Management of Production Systems" and "Management of Software Companies".

Due to the fact that the training programs offered to students by the Institute of Sectorial Management are applicationoriented, the Russian and the international real estate markets represent the main object of research carried out by the Department of Real Estate Economics.

Real estate represents one of the sectors of the Russian economy, for which training of professionals has been provided for over a decade. It is the primary focus of the scientific analysis conducted by the Institute of Sectorial Management. The trends and approaches to regulation of the Russian real estate market are subjected to thorough consideration. The scientific developments are subsequently used in "green" construction innovative technologies throughout the entire life cycle of a construction project, from conception to operation of the building.

The director of the Institute of Sectorial Management, the Dean of the Faculty of Real Estate Economics at the RANEPA, Doctor of Economic Sciences, Professor, Head of the Department of Real Estate Management and Land Tenure Problems, Elena Ivankina, was unanimously elected a new president of the branch at the general meeting of FIABCI-Russia in April 2014. For the first time a representative of academic circles rather than a head of a real estate, a development or a construction company was elected for this position. This confirms the relevance and importance of the development of education in the field of real estate, which is considered to be of great importance within the framework of the international association of professionals engaged in the relevant type of commercial activity. The importance of integration of 
professional communities into the teaching process has been emphasized by many experts.

“... the Department of Real Estate Economics (at the Institute of Sectorial Management of RANEPA) will translate FIREC, as well as Global 1 and Global 2 courses into the Russian language and adapt them to Russian conditions. These training programs, designed for training of consultants for the international real estate market, will be included in the training courses for masters and MBA students majoring in real estate management. The students will receive FIABCI certificates upon course completion, which will greatly expand their career opportunities" (Ivankina \& Kurilenko, 2014)

Application of research findings of the Institute of Sectorial Management is feasible subject to development of the following disciplines: "Real Estate Economics", "Project and Program Management", "Real Estate Management", and "Real Estate Development". The research findings may also be used by federal and regional authorities for the purposes of scientific and methodological support of the regional residential construction development programs.

The research findings are recommended for review to regional and federal ministries and agencies, specifically: the findings of the research and development activities carried out by the Institute of Sectorial Management are application-oriented in character; the materials obtained during the study were submitted to the Housing and Communal Services Reforming Assistance Fund, as well as to the heads of a number of regions and territories of the Russian Federation.

The findings of the scientific research conducted by the Institute of Sectorial
Management are of practical value and can be used in the preparation of proposals on the potential paths of the public-private partnership (hereinafter referred to as "PPP") in the field of affordable housing, engineering and social infrastructure, as well as the development of specific measures of implementation of the PPP at the regional level.

As one of the largest structural units of RANEPA, the Institute of Sectorial Management fully implements the principle of continuing education and offers human resources training programs for professionals engaged in the institutional reform of the Russian economy.

\section{References}

Inankina, E.V., \& Kurilenko, V.I. (2014). The prospects of development of the International Real Estate Federation (FIABCI) in Russia. Mechanization of Construction, № 7 p. 3-10.

Mau, V.A., \& Klyachko, T.L. (2013). Human capital development - a new social policy. Moscow, Russian Federation: Case.

\section{Web references:}

http://www.ranepa.ru/eng/

http://www.ism.ranepa.ru/ 


\title{
КОНТИНУИРАНА ЕДУКАЦИЈА МЕНАЏЕРА КАО ОСНОВА ИНОВАЦИОЛЕ ЕКОНОМИЈЕ (ИСКУСТВО РУСКЕ ПРЕДСЕДНИЧКЕ АКАДЕМИЈЕ НАЦИОНАЛНЕ ЕКОНОМИЈЕ И ЈАВНЕ УПРАВЕ - РАНЕПА) \\ Елена Косарева и Наталија Сафронова
}

\begin{abstract}
Извод
У овом раду је представљено искуство успостављања система континуиране едукације у руској председничкој академији националне економије и јавне управе (РАНЕПА), са циљњм да подржи институционалну реформу руске економије. Поред општих података о Академији, дат је и преглед научно-истраживачких активности ове институције. Приказана је и улога Академије у формирању образовног простора у Русији. Као посебан пример је дата пракса креирања новог кластера образовања и обуке у оквиру цтруктурне дивизије Академија - Институт за секторски менаџмент.
\end{abstract}

Кључне речи: обука кадрова, Руска Федерације, Гајдар форум, кластер образовања и обуке, институционалне реформе 